\title{
SOME BIOLOGY ASPECTS OF OXEYE SCAD, SELAR BOOPS CAUGHT FROM BITUNG WATERS WITHIN MOLLUCCAS SEA OF INDONESIA
}

\author{
Saranga Rudi*, Arifin Mohammad Zainul, Simau Silvester, Kalesaran Jerry D. \\ Marine and Fisheries Polytechnic of Bitung, Bitung City, North Sulawesi, Indonesia \\ ${ }^{*}$ E-mail: rudisaranga@yahoo.com
}

\begin{abstract}
Trevally species of oxeye scad, Selar boops is one of small pelagic species which an economic values. The species was exploited throughout the year by small-scale fishermen in Bitung waters using handline. The aim of this study was to determine some biological aspects of $S$. boops in Bitung waters area through measuring their lengths and weights, sex ratios, stages of oocyte, gonadosomatic index and type of spawning. Samples of fish were randomly collected each month at Bitung Oceanic Fishing Port during February 2016 to January 2017. Total samples of fish were used in this study 1659 consisting 841 male, 754 female, and unidentified 64. Length at first maturity (Lm) was $16,3 \mathrm{~cm}(\mathrm{FL})$ and asymptotic length $\left(L^{\infty}\right)$ was $26,4 \mathrm{~cm}(\mathrm{FL})$. The overall length-weight relationships were $W=0,01136 * L^{3,1640}\left(R^{2}=0,988\right)$ with a positive allometric growth. The sex ratios were balanced between males and females. The average of gonadosomatic index was 1.02 while the lowest and highest values was 0.03 and 6.96 with partial spawning type. Identification and genetic confirmation of $S$. boops using DNA-COI analysis.
\end{abstract}

\section{KEY WORDS}

Biology aspects, DNA-COI, Selar boops, marine species.

Carangidae is estimated to have 25 total of genera and about 140 species in the world (Randal et al 1990). There are 3 genus of travellies in the world that has been declared valid namely Selar crumenophthalmus, Selar boops and Selaroides leptolepis. Trevally is a genus of the Carangidae which classified as small pelagic fish species that live in groups (Carpenter \& Niem 2001) and migratory surrounding coastal waters at depths of $30-100 \mathrm{~m}$ (Froese \& Pauly 2014) and distributed in the Indo-Pacific waters (Smith-Vaniz 1995). S. boops is species co-occurs with Selar crumenophthalmus on continental shelf waters where common between 20 and $100 \mathrm{~m}$ and it is most often found over soft bottom or seagrass bed areas (Gomelyuk 2009; Smith-Vaniz \& Williams 2016), but it is also known to sometimes frequent coral and rocky reefs (Paxton et al 1989). This species forms large diurnal aggregations, dispersing at night to feed on planktonic and benthic invertebrates (crabs and shrimps) and small fishes (Smith-Vaniz 1986, Paxton et al 1989). The maximum size for this species is about $26 \mathrm{~cm}$ TL (Allen \& Erdmann 2012).

Oxeye scad, $S$. boops locally name known as Tude Batu. This spesies is one of small pelagic resources in Bitung waters area and is one of the commercially important fishes in Indonesia. Yet, biological aspects data concerning the $S$. boops are lacking in Indonesian waters even in other countries. The research information about $S$. boops has been done by Hutubessy (2011), Isa et al (1996), and Gumanao et al (2016). There are virtually no data concerning the stages of maturity, spawning or other life history traits for this species and acccording the International Union for Conservation of Nature and Natural Resources (IUCN), this spesies was categorized red list of threatened species (Smith-Vaniz \& Williams 2016). The purpose of the present study was to determine some aspects of the biology of $S$. boops in Bitung waters area, within Mallucas Sea of Indonesia. The results of this study as initial information related to some biologi aspects of $\mathrm{S}$. boops and will provide valuable information to all stakeholders. 


\section{MATERIALS AND METHODS OF RESEARCH}

Study site and sampling procedure. A total of 1659 oxeye scads (841 males, 754 females and 65 un-identification individuals) was randomly sampled from the commercial catch in the local fish in Bitung city, from February 2016 to January 2017. The samples were caught from Bitung waters area within Mallucas Sea of Indonesia. The samples were fresh captured fish. Measurements and dissections were quickly performed to prevent measurement bias and sample decay.

Research location. This research was conducted in Bitung Oceanic Fishing Port (BOFP), Bitung City, North Sulawesi Province, Indonesia. Geographically of BOFP located at $01^{\circ} 26^{\prime} 42$ "N - 12512'24"E (Figure 1).

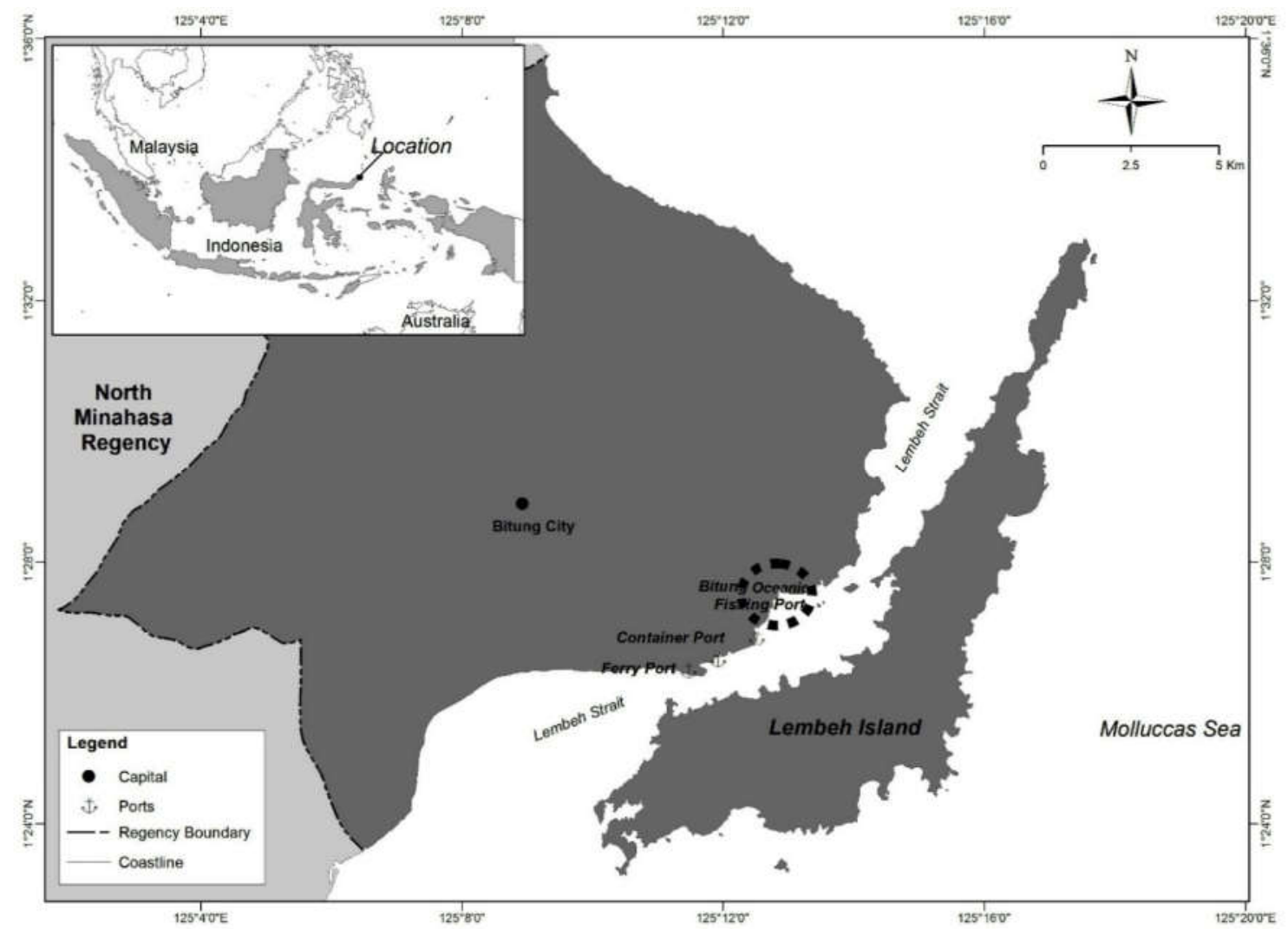

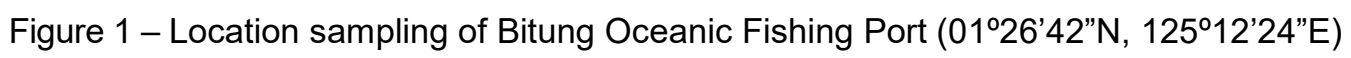

Measurements. Each individual fish was measured for the fork length ( $F L)$ to the nearest $0.1 \mathrm{~cm}$ and body weight was measured using portable and battery power weighing scale of max. $500 \mathrm{~g}(0.1 \mathrm{~g})$. The fish were later dissected from the abdominal region and their sexes were determined by visual examination of the gonads. The gonads werethen removed carefully and their weights taken to the nearest $0.01 \mathrm{~g}$ with the portable electronic compact scale.

Species identification. The identification of $S$. boops was confirmed by DNA molecular analysis. DNA genome was collected from dorso-lateral tissue of the fish, preserved in acetone, and stored at $-50^{\circ} \mathrm{C}$ prior to laboratory procedure. DNA extraction (Asahida et al 1996) was performed in $1.5 \mathrm{ml}$ volume containing $600 \mu \mathrm{l}$ TNESU 8 buffer extract (TNESUrea: $8 \mathrm{M}$ urea; $10 \mathrm{mM}$ Tris- $\mathrm{HCl}, \mathrm{pH} 7.5 ; 125 \mathrm{mM} \mathrm{NaCl} ; 10 \mathrm{mM}$ EDTA; $1 \%$ SDS), and $300 \mu \mathrm{l}$ $\mathrm{Cl}$. The mix solution was incubated at $65^{\circ} \mathrm{C}$ for $2 \mathrm{~h}$. The DNA was extracted with PhenolChloroform (1:1), 2 ethanol, $0.3 \mathrm{M} \mathrm{NaCl}$, and TE Buffer $(10 \mathrm{mM}$ Tris- $\mathrm{HCl}, \mathrm{pH}$ 8,0; $1 \mathrm{mM}$ EDTA). Partial DNA region COI was amplified using PCR with primer (Ward et al 2005):

- FF2D: 5'-TTCTCCACCAACCACAARGAYATYGG-3'

- FR1D: 5'-CACCTCAGGGTGTCCGAARAAYCARAA-3' 
PCR was performed at $10 \mu \mathrm{l}$ volume containing dd $\mathrm{H}_{2} \mathrm{O} 5.65 \mu \mathrm{l}$, 10X Fast Buffer $1 \mu \mathrm{l}$, dNTP mix $1 \mu \mathrm{l}$, each primer of $0.5 \mu \mathrm{l}$, SpeedSTAR taq polymerase 0,05 $\mu \mathrm{l}$, and DNA template $0,5 \mu \mathrm{l}$ based on protocol in Takara Inc., adjusted for Taq Enzyme SpeedSTAR HS DNA polymerase. PCR were carried out over 35 cycles with program setting: denaturation at $95^{\circ} \mathrm{C}$ for $30 \mathrm{~s}$, annealing at $55^{\circ} \mathrm{C}$ for $30 \mathrm{~s}$, and extension at $72^{\circ} \mathrm{C}$ for $30 \mathrm{~s}$. PCR product, after visualized in $1 \%$ agarose gel, was purified following Kit protocol of GE ExoSAP-IT. Sequencing was done by Firstbase Malaysia. The sequence was aligned (reverse complement, pairwise alignment, and consensus) using BioEdit (Hall 1999). Phylogenetic reconstruction of sequences DNA region $\mathrm{COI}$ were based on maximum-likelihood method with MEGA6 (Tamura et al 2013), bootstrap method with 1000 replicates and all parameters were set at default (lkejima et al 2004).

Sex ratio. The sex of each specimen was identified by physical examination of the gonads. The proportion of the two sexes relative to one another was used to calculate the sex ratio. Based on gonad identification, Chi-square $\left(x^{2}\right)$ test was carried out on the observed male and female specimens to show the level or proportion of differentiation from the expected 1:1 ratio, if $x^{2}$ test $>x^{2}$ table, Ho is accepted (Ayo-Olalusi 2014).

Oocyte development and maturity classification. To examine oocyte development and microscopically verify the precision of the macroscopic maturity scale, a subsample of 19 ovaries were fixed in $10 \%$ buffered formalin for histological analyses. Once fixed, a 4-mm thick transverse section was taken from the middle of each gonad, dehydrated through a series of alcohol and solvent solutions and infiltrated with paraffin wax on an automatic tissue processor (Sakura, Japan). A rotary microtome (HM 310, Thermo Fischer Scientific Inc., Germany) was used to cut 5- $\mu \mathrm{m}$ thick sections, which were stained with haematoxylin and eosin, cover-slipped with a mounting medium, and examined under a Nikon SMZ1000 light microscope with a Nikon DXM1200F digital camera.

Gonad stages identification. Macroscopic identification of female gonads was done based on five point maturity scales for partial spawners (Holden \& Raitt 1974). The gonad developmental stages are categorised as immature (ovaries about $1 / 3$ length of the body cavity), maturing (ovary about $1 / 2$ length of the body cavity and ovary are pinkish without visible ova to the naked eyes), ripening (ovary takes about $2 / 3$ length of the body cavity and ovary with granular appearance), ripe (ovary from $2 / 3$ to the full length of the body cavity; ovary with conspicuous superficial blood vessels) and last stage as spent (ovary shrunken to about half-length of the body cavity and loose walls). Fresh gonads were usually removed from the fish within a few hours of capture, and their sex and stage of reproductive maturity determined using a macroscopic staging system. Gonads obtained from coastal fishers could usually be weighed fresh $(0.01 \mathrm{~g})$. Two or three transverse cuts were then made through each gonad to ensure proper fixation before placing them into a perforated cellophane bag and then into plastic drums containing $10 \%$ formalin in seawater.

Gonadosomatic index. The gonadosomatic index was calculated as a percentage of body mass. It is represented by the formula: GSI = [Gonad Weight / Total Tissue Weight (weight of fish)] x 100. This was calculated for each individual and a monthly average for each sex was established. The GSI calculation were pooled based on the sex of fish regardless of the gonad maturity stage.

Isometric growth dimension. Isometric growth dimension was estimated using lengthweight relationship (LWR). Cube law of length-weight relationship was transferred into logliner following the quation (Froese 2006):

$$
W=a^{*} L^{b}
$$

Where: 'W' stands for weight $(\mathrm{g})$, ' $\mathrm{L}$ ' stands for fork length (cm), ' $a$ ' is constant, and 'b' is isometric growth dimension. The constant ' $a$ ' and ' $b$ ' were derived by the method of linier least squares. To test ' $b$ ' values against the value of ' 3 ', Student's t-test was employed to predict any significant deviation (Snedecor \& Cochran 1967).

The t-statistic was calculated as follows: 


$$
t=(b-3) / S E b
$$

Where: SEb $=$ standard error of 'b' $=$ SEb $=\sqrt{ }(1 /(n)) \times\left[(\text { Sy/Sx })^{2}-b^{2}\right]$, Sx and Sy are the standard deviations of $x$ and $y$, respectively. The t-value was compared with t-table value ( $n$ $=1659$ ) for degrees of freedom at $5 \%$ significance level.

Length at first capture $(L c)$ and Length at first maturity $(L m)$. We using spawning potential ratio (SPR) analysis provides an overview of the length distribution of fish, Lc and $\mathrm{Lm}$ of fish and the condition of $S$. boops in Bitung waters. In species where the males and females have distinct and different growth characteristics, the SPR Analysis focuses on the size structure and size of maturity of the females (Prince 2014). SPR is the proportion of spawning fish that are not caught in fishing policy (Walters \& Martell 2004). SPR analysis was carried out by using assessment which is web-based in www.barefootecologyst.com.

\section{RESULTS AND DISCUSSION}

Species identification. Only one sequence $S$. boops was used in phylogenetic analysis caught from Bitung waters area. Alignment of this sequence (690 bp) and based on estimates of evolutionary divergence identification resulted in $99 \%$ similarity to $S$. boops voucher ARO37 and S. boops voucher DBMF-M12 sequences from genBank (Table 1). The visualization of the morphology of $S$. boops from Bitung waters and phylogenetic are given in Figure 2 and 3.

Table 1 - Estimates of evolutionary divergence between sequence $S$. boops from Bitung with sequences from genBank (https://blast.ncbi.nlm.nih.gov)

\begin{tabular}{|c|c|c|c|c|c|c|c|}
\hline $\begin{array}{c}\text { Local name } \\
\text { sequence }\end{array}$ & Description & Total score & Query cover & Query length & E value & Ident. & Accession \\
\hline \multirow{2}{*}{ Tude Batu } & S. boops voucher ARO 37 & 1188 & $95 \%$ & 690 & 0.0 & $99 \%$ & KF009659.1 \\
\cline { 2 - 8 } & S. boops voucher DBMF-M12 & 1171 & $94 \%$ & 690 & 0.0 & $99 \%$ & HQ560953.1 \\
\hline
\end{tabular}

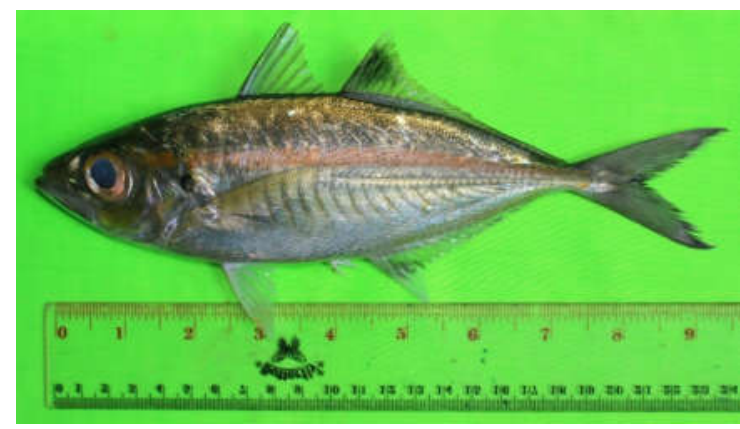

Figure $2-S$. boops collected from Bitung waters area that used for species identification

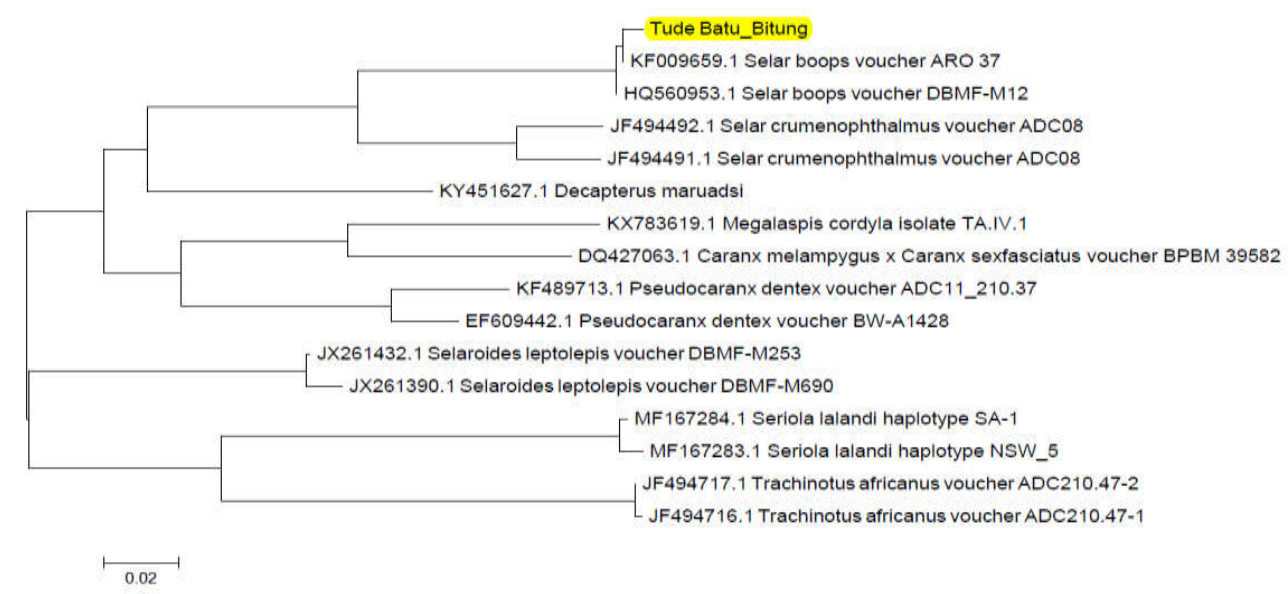

Figure 3 - Phylogenetic reconstruction (maximum likelihood-joining method) of sequences mt DNA region $\mathrm{COI}$ of sekuen sample from Bitung (Tude Batu_Bitung) 

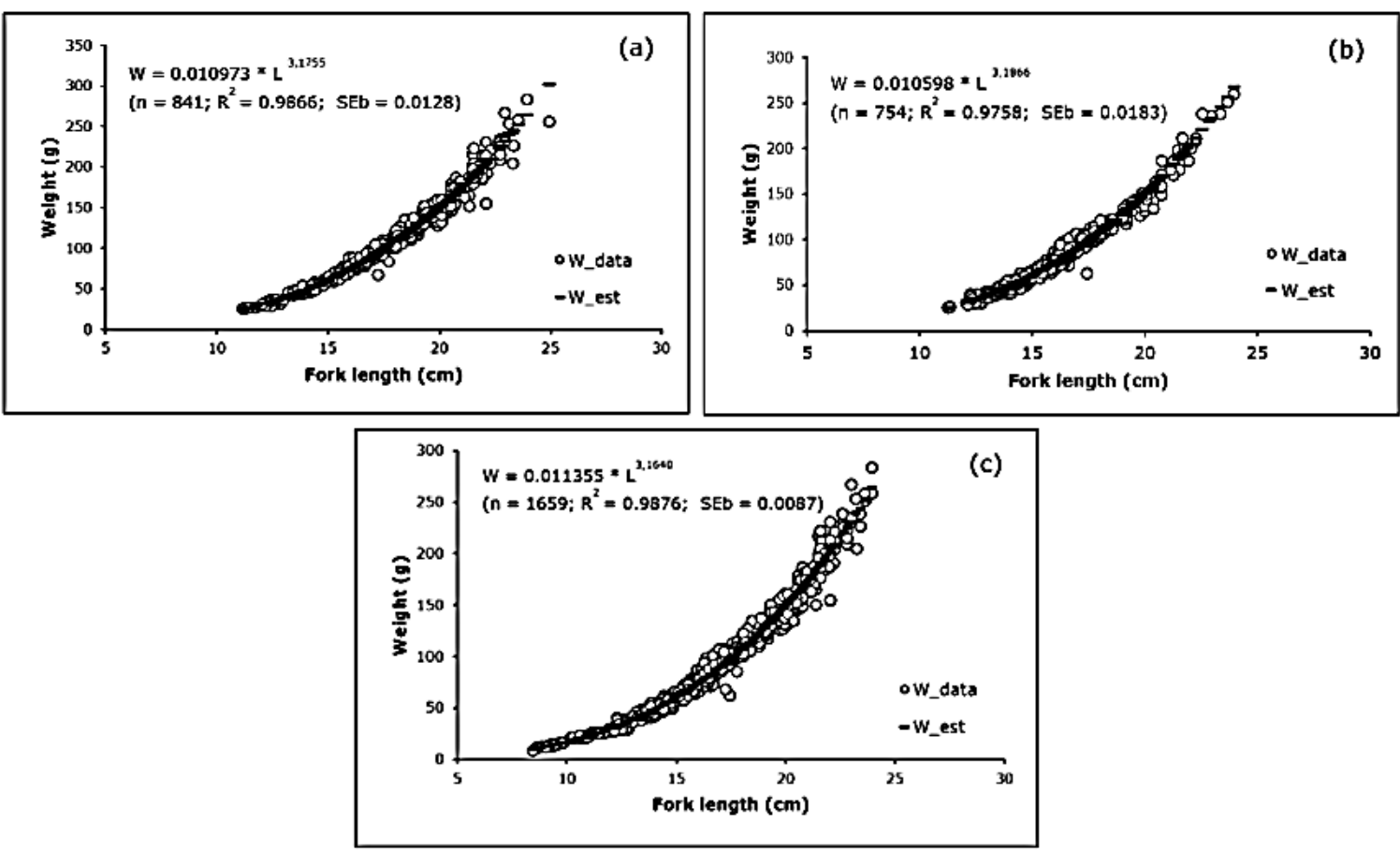

Figure 3 - Isometric growth dimension derived from length-weight equation of $S$. boops:

(a) male; (b) female; (c) overall

Isometric growth dimension. A total of 841 and 754 randomly selected specimens of males and females were collected, with fork length and weight ranging from $11.2-25.0 \mathrm{~cm}$ and $25.0-282.0 \mathrm{~g}$ for males and $11.3-24.0 \mathrm{~cm}$ and $25.0-258.5 \mathrm{~g}$ for females. The scatters diagram showing the allometric relationship for male and female is given in Figure $4 \mathrm{a}$ and $4 \mathrm{~b}$. The LWR for male and female were established as $W=0.010973{ }^{*} L^{3,1755}\left(R^{2}=0.9866\right.$; SEb $=0.0128)$ and $W=0.010598{ }^{*} L^{3,1886}\left(R^{2}=0.9758 ;\right.$ SEb $\left.=0.0183\right)$, respectively. A overall LWR was established for all sample as $W=0.011355 * L^{3,1640}\left(R^{2}=0.9876\right.$; $\left.\mathrm{Seb}=0.0087\right)$ (Figure 4c). The student's t-test of slope with $b=3$ revealed the existence of positive allometric growth for both sexes (T-test $>$ T-table) with confidence interval ' $b$ ' was $3.1504<b<3.2006$ for male and $3.1526<b<3.2254$ for female (Table 2).

Table 2 - Values for t-test for the slopes of regression equations with theoretical $b=3$ of $S$. boops from landings at BOFP during the study

\begin{tabular}{|c|c|c|c|c|c|}
\hline Sex & $\mathrm{b}$ (slope) & Interval of b & SEb & T-test & T-table \\
\hline Male & 3.1878 & $3.1504-3.2006$ & 0.0128 & 13.74 & 1.96 \\
\hline Female & 3.1886 & $3.1526-3.2245$ & 0.0183 & 10.29 & 1.96 \\
\hline Overall & 3.1640 & $3.1470-3.1810$ & 0.0087 & 18.95 & 1.96 \\
\hline
\end{tabular}

Sex ratio. Sex for $S$. boops with $N=1659$ showed males dominated by $50.69 \%$ $(n=841)$ while females only $45.450 \%(n=754)$ and not identified $3.86 \%(n=64)$. Chi square $\left(x^{2}\right)$ test revealed that the sex ratio was not significantly different deviate from the normal proportion ratio 1:1 (Tables 3 ) and number of male and female samples during the study is presented in Figure 4.

Table 3 - Chi square test for sex ratios of $S$. boops collected from BOFP during the study

\begin{tabular}{|c|c|c|c|c|c|}
\hline Sex & Observation $(\mathrm{O})$ & Expected $(\mathrm{E})$ & $\mathrm{O}-\mathrm{E}$ & $(\mathrm{O}-\mathrm{E})^{2}$ & $(\mathrm{O}-\mathrm{E})^{2} / \mathrm{E}$ \\
\hline Male & 841 & 797.5 & 43.5 & $1,892.25$ & 2.373 \\
\hline Female & 754 & 797.5 & -43.5 & $1,892.25$ & 2.373 \\
\hline Total & 1595 & & & & 4.756 \\
\hline
\end{tabular}


The Chi-square test was used to determine if a population contains equal proportion of males and females and it is a test of how well a model fits the observed data. Hypotesis: Ho = Male: Female is $1: 1, \mathrm{Hi}=$ Male: Female is not 1: 1 . If $\mathrm{n}=2$, degree of freedom (df) $=2-1=$ 1. From the critical values of the Chi-square distribution table at $\mathrm{df}=1, x^{2}{ }_{0.05,1}=3.841$. The calculated value 4.746 is more than table value, the null hypotesis Ho is accepted meaning proportion stable.

Table 4 - The estimated sex ratio values for $S$. boops collected from BOFP during this study

\begin{tabular}{|l|c|c|c|c|c|}
\hline \multicolumn{1}{|c|}{ Month of observation } & \multirow{2}{*}{ Male } & \multirow{2}{*}{ Female } & \multirow{2}{*}{ Un-identified } & \multicolumn{2}{c|}{ Proportion } \\
\cline { 3 - 6 } & & & & Male & Female \\
\hline February 2016 & 29 & 71 & 19 & 0.41 & 1 \\
\hline March 2016 & 82 & 42 & 40 & 1 & 0.51 \\
\hline April 2016 & 106 & 51 & - & 0.95 & 1 \\
\hline May 2016 & 76 & 80 & - & 1 & 0.79 \\
\hline June 2016 & 66 & 52 & - & 1 & 0.86 \\
\hline July 2016 & 71 & 61 & - & 1 & 0.92 \\
\hline August 2016 & 58 & 63 & - & 0.73 & 1 \\
\hline September 2016 & 98 & 78 & - & 0.74 & 1 \\
\hline October 2016 & 49 & 67 & - & 0.87 & 1 \\
\hline November 2016 & 53 & 72 & 1 & 1 & 0.52 \\
\hline December 2016 & 59 & 68 & - & & 1 \\
\hline January 2017 & 94 & 49 & 4 & & \\
\hline
\end{tabular}

Macroscopic identification at the gonad maturity stage: Macroscopic identification of the gonads was carried out for six months, from February 2016 to July 2016, to obtain an overview of gonadal development. The ovaries were orange in color, thin and ova were not visible to the naked eye during gonad stage one. Color, size and ova visibility gradually increased as the ovaries matured. Ovaries of gonad stage four appeared bright orange in color with conspicuous superficial blood vessels and ripe ova were visible to the naked eye and occupied almost the entire body cavity (Figure 5). The ranges of gonad weight in this study each stages was obtained that stage I total samples 324 range $0.02-0.19 \mathrm{~g}$ (mean value $=0.09 \pm 0.04$ ) and the maximum length was $16.9 \mathrm{~cm}$, stage II total samples 128 ranges of gonad weight $0.09-0.43 \mathrm{~g}$ (mean value $=0.18 \pm 0.07$ ) and the maximum length was 17.4 $\mathrm{cm}$, stage III total samples 167 ranges $0.18-1.99 \mathrm{~g}$ (mean value $=0.79 \pm 0.46$ ) and the maximum length was $20.1 \mathrm{~cm}$, stage IV total samples 67 ranges $1.09-3.97 \mathrm{~g}$ (mean value $=$ $2.64 \pm 0.79$ ) and the maximum length was $21.6 \mathrm{~cm}$, and stage $V$ total samples 68 ranges 3.00 $-15.81 \mathrm{~g}$ (means value $=6.30 \pm 2.91$ ) and the maximum length was $24.0 \mathrm{~cm}$. Total sample of immature were 452 and matures were 302.

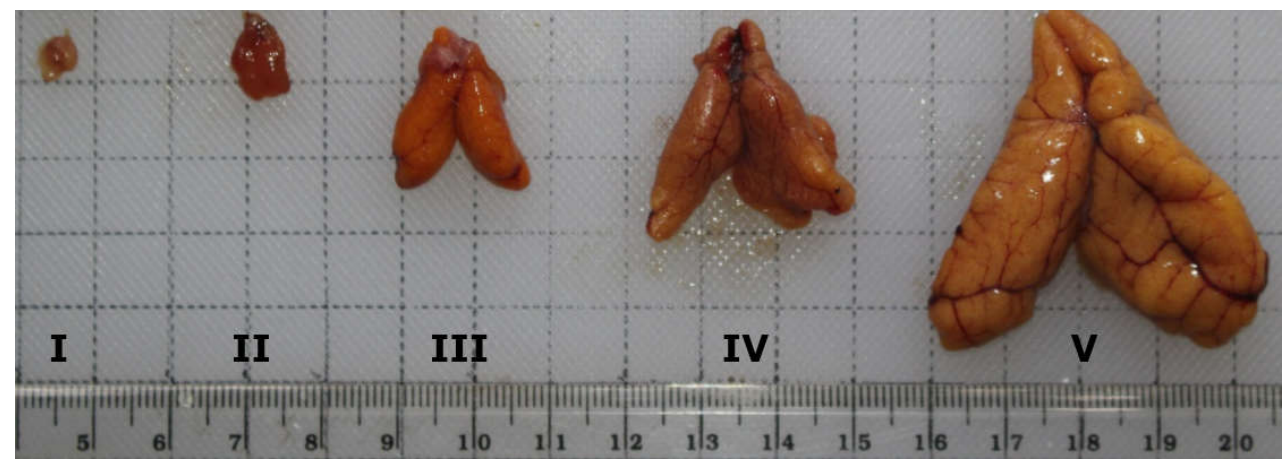

Figure 5 - Ovary size variation in S. boops: from right to the left, as the ovaries matured their size and development increased

Gonad stages identification. According to microscopic identification we obtained 5 stages variation size of oocytes development and this result explain that $S$. boops cacth in Bitung waters is partial spawning type (Figure 6). 
Stage I

Only oogonia (og) and primary growthoocytes (po) with large pink nuclei are present. Ovary wall is thin. Atresia may occur in the present and all of the following classes. Oocyte diameter ranges 10.56-37.84 $\mu \mathrm{m}$ (average $20.77 \mu \mathrm{m}$ ). Scale bar $(\mathrm{Sb}): 100 \mu \mathrm{m}$.

\section{Stage II}

Secondary growth oocyte, primary growth oocytes and oogonia are present. Ovary wall is thin in first time spawner, thinck in repeat spawners. The ratio nucleus (nu) to oocyte area has decreased. Oocyte diameter ranges 25.52-58.08 $\mu \mathrm{m}$ (average $34.06 \mu \mathrm{m})$. Sb: $100 \mu \mathrm{m}$.

\section{Stage III}

Secondary growth oocytes containing yolk granules (yg), primary growth oocytes and oogonia are present. The oocyte diameter increases dramatically during III. By the end of class III the cytoplasm is half filled with yolk granules. Oocyte diameter ranges 27.28-132.90 $\mu \mathrm{m}$ (average $76.12 \mu \mathrm{m}$ ). Sb: $200 \mu \mathrm{m}$.

\section{Stage IV}

Secondary growth oocytes in the nuclear migration stage, primary growth oocytes and oogonia are present. By end of class IV oocytes are completely filled with yolk, cortical alveoli are pressed against cell membrane $(\mathrm{cm})$ and nucleus begins migration towards micropyle. Oocyte diameter ranges 75.68-192.30 $\mu \mathrm{m}$ (average $117.66 \mu \mathrm{m})$. Sb: $200 \mu \mathrm{m}$.

Stage V

Final growth oocytes with hydrolyzed yolk granules (hyg), primary growth oocytes and oogonia are present. The nucleus has disintegrated and is no longer visible. Oocyte diameter ranges 177.80-239.40 $\mu \mathrm{m}$ (average $208.22 \mu \mathrm{m}$ ). Sb: $200 \mu \mathrm{m}$.
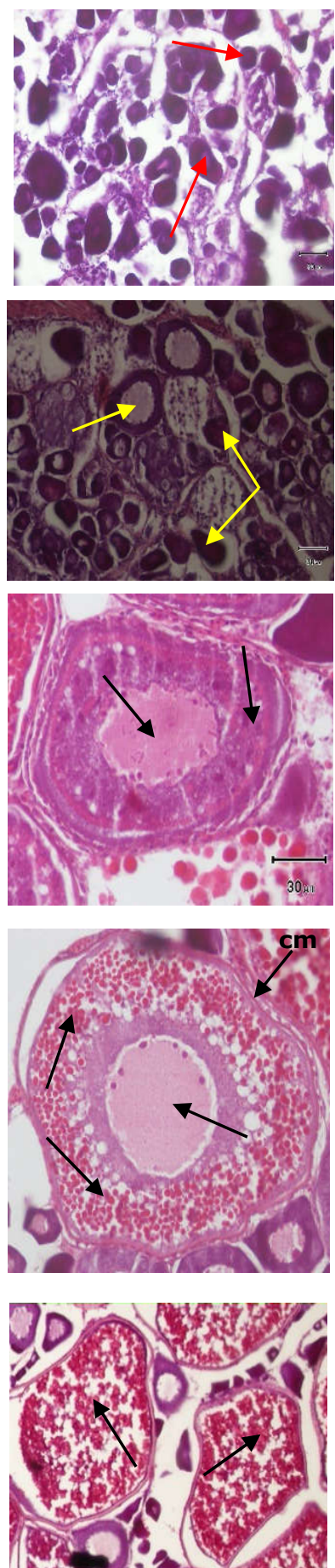

Figure 6 - Histological identification female gonads of $S$. boops

Gonadosomatic index. GSI value was fluctuated with range $0.46-1.89$ and the highest and the lowest mean GSI value in October 2016 and September 2016. The average of GSI increased 1.05 on May 2016 from 0.63 on April 2016 and become decreased 0.70 on June 2016. After that, peak of GSI average increased 1.89 on October 2016 and become decreased 1.19 on November 2016 (Figure 7).

Length at first capture (LC) and Length at first maturity $(\mathrm{Lm})$. Based on SPR analysis, we can see the distribution values of $S$. boops caught during the research and most of the fish caught have a fork length of $16 \mathrm{~cm}$ (Figure 8). Length at first capture was $14.26 \mathrm{~cm}$ and length at first maturity was $16.30 \mathrm{~cm}$. The comparison of length at first capture (LC) and 
length at first maturity $(\mathrm{Lm})$ of $S$. boops shows in Figure 9. The value of SPR fishing rate relative to mortality (F/M) was 2.23 and asymptotic length $(L \infty)$ was $26.40 \mathrm{~cm}$.

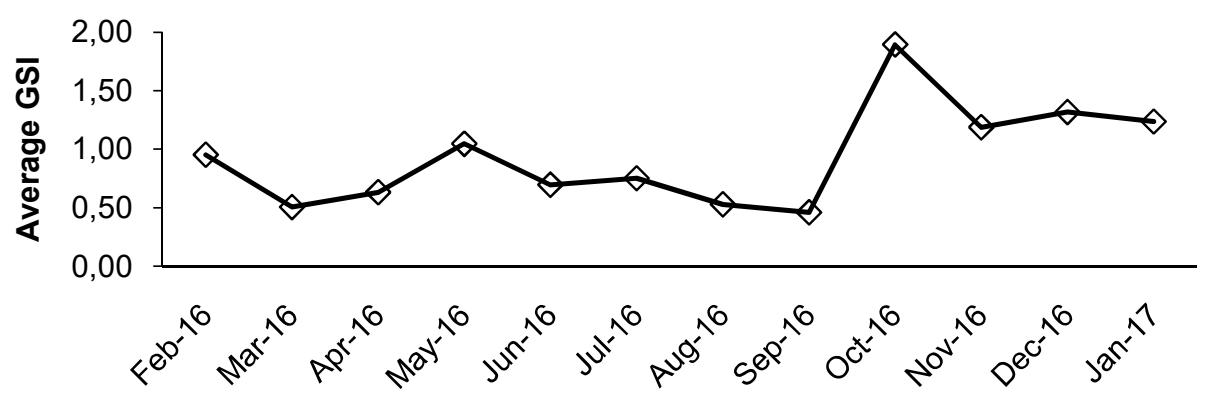

Figure 7 - Monthly average GSI of female S. boops

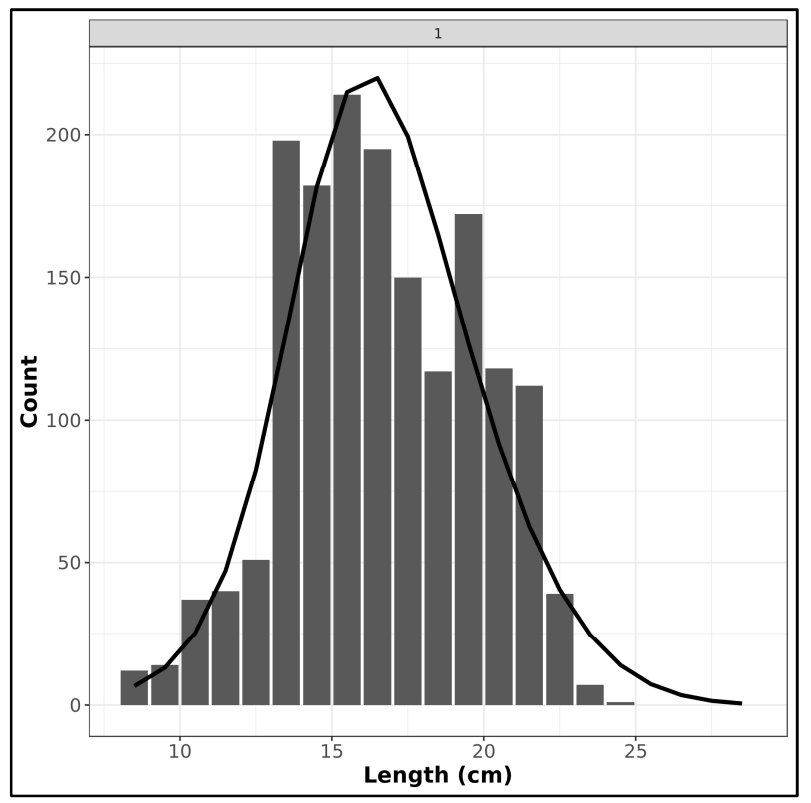

Figure 8 - Length distribution diagram of $S$. boops

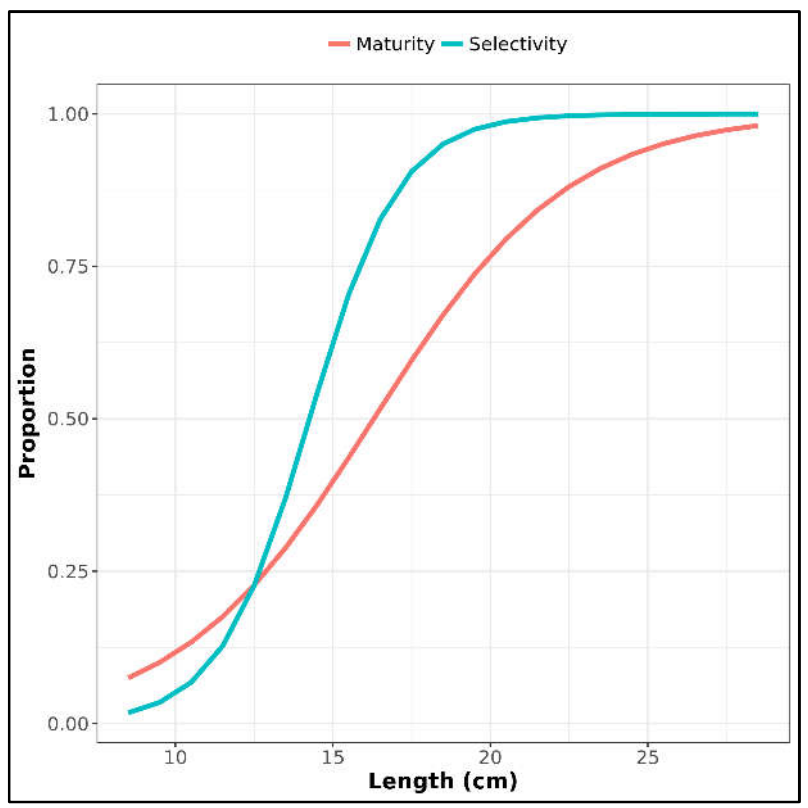

Figure 9 - Comparison of length at first capture (Lc) and Length at first maturity (Lm) of S. boops 
Figure 9 above shows trends in which Lc $<\mathrm{Lm}$, which means that the caught fishes are still immature. This condition was not good based on the fish biology aspect, because the generally fish were caught immature and suspected have not reproduced. If this condition is allowed to occur continuously it can be dangerous for $S$. boops stock in Bitung waters. One of indication that the utilization of fish resources doing well based on biologically if the average size of the caught fish is greater than the size of the first maturity (Lc $>\mathrm{Lm}$ ), otherwise if Lc $<\mathrm{Lm}$ can disturb the stability of the stock indeed cause over fishing of $S$. boops in Bitung waters. The value of F/M from the analysis shows that $S$. boops has F/M values of $>1$ which means that the number of fishing mortality is higher than natural mortality due to fishing activity. Uncontrolled fishing can lead to a decrease in the average age and size of fish (Trippel 1995; Hutchings 2004; Allan \& Castillo 2007). Walters \& Martell (2004) state that fishing exploitation should be selective to the size of the fish, it's intended to avoid the occurrence of recruitment overfishing and growth overfishing.

This species is restricted to the Indo-West Pacific except for one confirmed record from Sesimbra Bay, Portugal. Elsewhere, this species has been recorded from the Andaman Islands to Vanuatu (Smith-Vaniz 1984), north to the Philippines, south to northern Australia (Paxton et al 1989), including Palau, New Caledonia and the Solomon Islands (Smith-Vaniz 1984). The result of genetic confirmation by phylogenetic tree (Figure 3), explains that the local type of trevallies namely Tude Batu which captured in waters around Bitung within Molluccas Sea is $S$. boops. Confirmation species using genetically is very important in the management of fish resources based on stock especially in Bitung waters area. By knowing valid species, sustainable management strategy can be developed. Phylogenetic trees have several uses such as summarizing the phylogeny of organisms by combining it with other data source analysis, studying co-speciation, calibrating the rate of molecular evolution, determining the age of estimate or genealogy, gene duplication analysis, estimating diversification rates, extinction, polymorphism, recombination, and population dynamics (Holder \& Lewis 2003).

The findings of the overall growth this study $b=3.164(F L)$ was similarly demonstrated by Isa et al (1996) and Gumanao et al (2016) which also it showed a positive allometry b = $3.174(\mathrm{TL})$ and $b=3.234(\mathrm{SL})$ respectively. Our result suggests that the $S$. boops in Bitung waters area grows faster in weight than length and the slope (b) value male slightly higher than female. This variation may be due to the difference in body forms, nutritional condition, and/or number of samples. Pauly (1984) suggested that 'b' value less than 3 indicated that fish becomes more slender as it increases in length and with a value greater than 3 denotes stoutness indicating allometric growth. Differences in the value of $b$ can give a picture of the differences in morphological characters of fish. The greater the value $b$ the fish body is plumper. For example in this study the body shapes female of $S$. boops is plumper compared to male. LWR can be used as a character for taxonomic unit differentiation and changes in relationships with life events in life such as metamorphosis, growth and maturity (Thomas et al 2003), and as an important tool in exploiting appropriate fishing practices, as well as managing fish populations (Ahmed et al 2011; Valeria et al 2014).

Based on sex ratio this study was found that proportion of male slightly higher than female (1.12:1) and Chi-square analysis shown that balance proportion between male and female. The sex ratio male to female was high in six months: March (1:0.51), April (1:0.48), June (1:0.79), July (1:0.86), September $(1: 0.80)$ and January $(1: 0.52)$ while female to male ratio was high in six months too: February (0.41:1), May (0.95:1), August (0.92:1), October $(0.73: 1)$, November $(0.74: 1)$ and December $(0.87: 1)$. This conveys that sex ratio during this study was fluctuated, however males were observed to be dominant than females. Although the sex ratio in nature often occur deviations from ideal conditions, at least proportion of females should be more than males (2:1) for schooling fish to keep population conditions stable for sustainability resources (Ball \& Rao 1984; Rahman et al 2013).

Gonadosomatic index (GSI) analysis for females of $S$. boops showed the lowest values in the beginning in February 2016 to September 2016 and progressively increased in October 2016 to January 2017 with the highest GSI recorded in October 2016. This indicated that the spawning periods of $S$. boops in Bitung waters area occurs throughout in October 
2016 to January 2017 with peak season in October 2016. Based on GSI analysis it can be concluded that spawning season of $S$. boops in Bitung waters area occurs once in a year. This conveys that fishing exploitation have to attention the spawning season of $S$. boops for recruitment to keep stocks stable. Based on macroscopic and microscopic identification at the gonad maturity stage, the percentage between immature and mature were $59.95 \%$ and $40.05 \%$, these result indicate that fish were caught generally immature. Sparre \& Venema (1998) state that if there are too few old fish the stok is overfished and the fishing pressure on the stock should be reduced and if the fish are caught too young there is growth overfishing of the stock.

\section{CONCLUSION}

This study provides the first description of S. boops in Bitung water area in Indonesia. There were strong relationships between the lengths and weights of $S$. boops where there is high dependency of weight on length. Both of sexes were experiencing positive allometry growth. Spawning periods of $S$. boops throughout in October to January with peak season in October. Gonad development during spawning season is one factor that affects gonadosomatic index of fish which is also evident in this study. Sex ratios for $S$. boops were balanced with partial spawning type. The length at first caught (Lc) is smaller than the length at first maturity $(\mathrm{Lm})$, therefore the some aspects of biology of $S$. boops related to legal-size are needed in fisheries management.

\section{REFERENCES}

1. Ahmed O. E., Mohammed E. A., Afra A. A., 2011 Length-weight relationship and condition factors of six fish species in Atbara River and Khashm El-girba reservoir, Sudan. International Journal of Agriculture Sciences 3(1):65-70.

2. Allan J. D., Castillo M. M., 2007 Stream ecology: Stucture and fuction of running waters. Second edition. Springer. Netherland.

3. Allen G. R., Erdmann M. V., 2012 Reef Fishes of the East Indies. Tropical Reef Research, Perth, Australia.

4. Asahida T., Kobayashi T., Saitoh K., Nakayama I., 1996 Tissue Preservation and Total DNA Extraction from Fish Stored at Ambient Temperature Using Buffer Containing High Concentration of Urea. Fisheries Science 62 (5): 727-730.

5. Ayo-Alalusi C. I., 2014 Length weight relationship, condition factor and sex ratio of African Mud Catfish (Clarias gariepinus) reared in flow-through systems tanks. Journal of Fisheries and Aquatic Science 9(5): 430-434.

6. Ball D. V., Rao K. V., 1984 Marine fisheries. Tata McGraw-Hill Publishing Company, New Delhi, pp. 51-73.

7. Carpenter K. E., 2001 The Living Marine Resources of the Western Central Pacific. Volume 4. Bony fishes part 2 (Mugilidae to Carangidae). Rome, FAO: pp. 2659-2737.

8. Froese R., 2006 Cube law, condition factor and weight-length relationships: history, meta-analysis and recommendations. Journal of Applied Ichthyology 22:241-253.

9. Froese R., Pauly D., 2014. Selar Crumenopthalmus in Fish Base. August 2015 version. N.p.: FishBase, 2014. http://www.fishbase.org.

10. Gomelyuk, V.E. 2009. Fish assemblages composition and structure in three shallow habitats in north Australian tropical bay, Garig Gunak Barlu National Park, Northern Territory, Australia. Journal of the Marine Biological Association of the United Kingdom 89(3): 449-460.

11. Gumanao G. S., Cardosa M. M. S., Muller B., Bos A. R., 2016 Length-weight and length-length relationships of 139 Indo-Pacific fish species (Teleostei) from the Davao Gulf, Philippines. Journal of Applied Ichthyology 1-9.

12. Hutubessy G., 2011 Encircling gillnet selectivity for oxeye scad (Selar boops CUVIER, 1833 ) in the coast of Waai, Ambon Island. Journal of Coastal Development 14(2): 125130. 
13. Hall T. H., 1999 BioEdit: a user friendly biological sequence alignment editor and analysis program for Windows 95/98/NT. Nucleic Acid Symposium Series 4: 95-98.

14. Holder M., Lewis P. O., 2003 Phylogeny estimation: traditional and Bayesian approaches. Nature Revies Genetics 4: 275-284.

15. Holden M. J, Raitt D. F. S., 1974 Manual of fisheries science Part 2: Methods of resource investigation and their application. Rome: FAO. http://www.fao.org/docrep/003/f0752e/F0752E05.htm\#ch5.2.2.2.

16. Hutchings J. A., 2004 The cod that got away. Nature 428: 899-900.

17. Ikejima K., 2004 Molecular Phylogeneny and Possible Scenario of Ponyfish (Perciformes: Leiognathidae) Evolution. Molluculer Phylogenet and Evolution. 31: 904-909.

18. Isa M. M., Abdullah S., Yasin A. H., 1996 Population structure of small pelagic fish off the east coast of Peninsular Malaysia. Fisheries Bulettin No. 99: 1-27. Department of Fisheries Malaysia. Ministry of Agriculture.

19. Paxton J. R., Hoese D. F., Allen G. R, Hanley J. E., 1989 Pisces. Petromyzontidae to Carangidae. Australian Government Publishing Service, Canberra.

20. Prince J., 2014 A technical report on an SPR size assessment of the blue swimmer crab fishery in Southeast Sulawesi. Technical Report for IMACS, USAID, $30 \mathrm{pp}$.

21. Pauly D., 1984 Fish Population Dynamics in tropical Waters: A Manual for Use with Programmable Calculators. ICLARM Studies and Reviews. No.8. 325 pp.

22. Rahman Y., Setyawati T. R., Yanti A. H., 2013. Characteristics of population Biawan fish (Helostoma temminckii Cuvier) in lake Kelubi, Tayan Hilir sub-district. Jurnal Protobiont 2(2): 80-86. [in Indonesian]

23. Randall J. E., Allen G. R., Steene R. C., 1990 Fishes of the Great Barrier Reef and Coral Sea. University of Hawaii Press, Honolulu. 506 pp.

24. Smith-Vaniz W. F., 1984. Carangidae. In: Fischer, W. and Bianchi, G. (eds), FAO species identification sheets for fishery purposes. Western Indian Ocean fishing area 51. Vol. 1., Food and Agriculture Organization of the United Nations (FAO), Rome.

25. Smith-Vaniz W. F., 1986 Carangidae. In: M.M. Smith and P.C. Heemstra (eds), Smith's Sea Fishes, Springer-Verlag, Berlin, pp. 638-661.

26. Smith-Vaniz W. F., 1995 Carangidae. Jacks, branches, cojinúas, shoemakers, cooks, Casabes, mackerel, mackerel, humpback, amberjack, pilot fish p. 940-986 in W. Fischer, F. Krupp, W. Schneider, C. Sommer, KE Carpenter and V. Niem (eds.) FAO Species Identification Guide for the Fines for Fisheries. Eastern Central Pacific.Vol. 3. FAO, Rome.

27. Smith-Vaniz W. F., Williams I., 2016 Selar boops, Oxeye Scad. The IUCN Red List of Threatened Species 2016: e.T18158262A115368272 . 7pp

28. Snedecor G. W, Cochran W. G. 1967 Statistical methods. 6th edition. Oxford and IBH Publishing Co, New Dehli. 593 pp.

29. Sparre, P \& S.C Venema. (1998). Introduction to Tropical Fish Stock Assessment. Part I: Manual. FAO Computerized Information Series (Fisheries). No. 12. FAO (Food and Agriculture Organization of the United Nations), Rome. 407p.

30. Tamura K., Stecher G., Peterson D., Filipski A., 2013 MEGA6: Molecular Evolutionary Genetics Analysis version 6.0. Molecular Biology and Evolution 30: 2725-2729.

31. Thomas J. S., Venus, Kurup B. M., 2003 Length-weigth relationship of some deep-sea fish inhabiting continental slope beyond $250 \mathrm{~m}$ depth along West coast of India. Naga, world fish center quart 26: 17-21.

32. Trippel E. A., 1995. Age at immaturity as a stress indicator in fisheries. BioScience 45: 759-771.

33. Valeria R. B. F., Michelato M., da Cruz T. P., Furuya W. M., 2014 Length-weight relationships and prediction equations of body composition of farm raised Astyanax aff. fasciatus (Actinopterygii: Characiformes: Characidae). Zoologia 31(6): 521-524.

34. Ward R. D., Zemlak T. S., Innes B. H., Last P. R., 2005 DNA Barcoding Australia's fish species. Philosophical Transaction of the Royal Society. B 360, 1847-1857.

35. Walters C. J., 2004 Fisheries ecology and management. Princeton University, 448 pp. 